Конференция "Религия и медицина"

\title{
PALLIATIVE HOPE AS A RESPONSIBLE DIALOGICALLY LIVED RELATION BETWEEN RELIGION AND MEDICINE
}

\author{
K. M. Vadíková \\ Doctor of Philosophy, Research-assistant, \\ Department of Ethics and Moral Philosophy of Faculty of Philosophy and Arts, \\ Trnava University (Trnava, Slovak Republic) \\ vadikova@yahoo.com \\ ORCID 0000-0002-2099-0991 \\ DOI: https://doi.org/10.34017/1313-9703-2019-1(13)-2(14)-78-84
}

\begin{abstract}
Анотация
Катарина Вадикова. Палиативната надежда като отговорен диалог между религията и медицината. В статията се анализира приноса на Врана, Гуардини, Войтила, Марсел в развитието на тезата за християнската диалогична хуманистична етика. Авторът се фокусира върху евристичния анализ на връзката между религията и медицината относно проявите на личната съвест и личната отговорност в контекста на палиативните грижи. Основният резултат от анализа е концепцията за палиативна надежда, възникването на която се дължи на отговорен диалог, основан на връзката между религия и медицина, и който не изисква специално медицинско и религиозно образование. Палиативната надежда се представя като специфична способност на човек да споделя страдания в личен диалог, с незадължително споменаване, но неизбежно участие на Бог, което води до увереност в най-добрия резултат и посоката на взаимната практика - към доброто.
\end{abstract}

Ключови думи: християнски диалогична хуманистична етика; религия; медицина; палиативни грижи; лична отговорност; палиативна надежда

\section{Анотація}

Катаріна Марія Вадікова. Паліативна надія як відповідальний діалог поміж релігією та медициною. В статті аналізується вклад Врани, Гуардіні, Войтили, Марселя в формування засадничих положень християнської діалогічної гуманістичної етики. Автор зосереджується на евристичному аналізі взаємозв'язку релігії та медицини щодо виклику особистої совісті та особистої відповідальності в умовах паліативної допомоги. Основним результатом аналізу є термін паліативної надії, застосування якого обумовлено відповідальним діалогом, що живе взаємозв'язком між релігією та медициною, не вимагаючи спеціальної освіти у галузі релігії чи медицини. Паліативна надія подається як специфічна здатність людини ділитися стражданнями в особистому діалозі, не обов'язково згаданою, але неминучою участю Бога, що призводить до підримки впевненості у найкращому результаті та спрямуванні обопільної практики - на добро.

Ключові слова: християнська діалогічна гуманістична етика; релігія; медицина; паліативна допомога; особиста відповідальність; паліативна надія 


\begin{abstract}
Abstrakt
Katarina Maria Vadíková. Paliatívna nádej ako zodpovedne dialogicky žitý vzt'ah medzi náboženstvom a medicínou. Článok vychádza z téz krest'anskej dialogicky personalistickej etiky (Vrána, Guardini, Wojtyla, Marcel). Zameriava sa na heuristickú analýzu vzt'ahu náboženstva a medicíny vzhl'adom k výzve osobného svedomia k osobnej zodpovednosti v podmienkach paliatívnej starostlivosti. Hlavným výsledkom analýz príspevku je pojem paliatívna nádej, ktorej aplikácia je podmienená zodpovedným dialogickým žitím vzłahu medzi náboženstvom a medicínou, a to bez požiadaviek na špeciálne vzdelanie v oblasti náboženstva alebo medicíny. Paliatívna nádej je predstavená ako špecificky l'udská schopnost' zdiel'at' utrpenie v osobnom dialogickom stretnutí, za nie nevyhnutne uvedomenej, ale nevyhnutnej spoluúčasti Boha, ktorej výsledkom je dôvera $v$ to najlepšie, čo má príst' - v dobro.
\end{abstract}

Klúčové slová: krest’anská dialogicky personalistická etika; náboženstvo; medicína; paliatívna starostlivost'; osobná zodpovednost'; paliatívna nádej

\begin{abstract}
Katarina Maria Vadíková. Palliative Hope as a Responsible Dialogically Lived Relation between Religion and Medicine. The article deals with the contribution of Vrana, Guardini, Wojtyła, Marcel in the formation of foundational provisions of Christian dialogical humanistic ethics. Author focuses on heuristic analysis of the relationship of religion and medicine in relation to the challenge of personal conscience to personal responsibility in palliative care conditions. The main result of the analysis of article is the term palliative hope, the application of which is conditional on responsible dialogue, the live relationship between religion and medicine, without requiring special education in the field of religion or medicine. Palliative hope means a specifically human ability to share suffering in a personal dialogue meeting, not necessarily mentioned but the inevitable participation of God, which results in confidence in the best to come - for the good.

Key words: Christian dialogical personalistic ethics; Religion; Medicine; Palliative care; Personal responsibility; Palliative Hope

Stanovenie zámeru, východísk a terminologicko-metodologického aparátu príspevku: Hlavným zámerom príspevku je sledovat' vzt’ah náboženstva a medicíny v podmienkach poskytovania paliatívnej starostlivosti s ohl'adom na problematiku osobnej zodpovednosti. Vzt'ah náboženstva a medicíny v podmienkach paliatívnej medicíny vykazuje rad špecifík, ktoré úzko súvisia s prevzatím osobnej zodpovednosti za rozhodnutia o poskytovaní a prijímaní zdravotníckej starostlivosti. Ide o interdisciplinárne komplikovaný dialóg všetkých zúčastnených, ktorý je na jednej strane bytostne intímnou výzvou vo svedomí aktérov starostlivosti, ale v podobe informácie sa prenáša do tvorby konsenzu v dialógu o naplnení požiadaviek zabezpečenia starostlivosti v konkrétnom prípade počas konzília i slúži ako vzorový kazuistický príklad modelového riešenia dilem pre budúce potreby poskytovania starostlivosti v oblasti paliatívnej medicíny.

Terminologické a metodologické východisko príspevku je zasadené do kontextu vybraných predstavitel'ov dialogického personalizmu (Vrána, Marcel, Guardini 2000, Wojtyla) v intenciách krest'anského svetonázoru (Guardini 2000). Žitý vzt'ah medzi náboženstvom a medicínou v životnom príbehu dialogickej osoby predstavuje prostredie, v ktorom sa fenomenologicky skúma a následne heuristicky analyzuje rozhodovací proces človeka v bolesti o zodpovednom prijatí bolesti, o spôsobe boja s ňou a účinkoch tzv. paliatívnej nádeje.

Zásadným východiskom príspevku je téza, že rozvinutie osobnej zodpovednosti nie je eticky možné visa versa, ale vždy vychádza z osobnej odpovede na výzvu vo svedomí dotknutých autonómnych osôb, tzn. nikdy nie naopak. V prípade, že by preniesli jednotliví aktéri tiaž svojej
\end{abstract}


osobnej zodpovednosti, či už na seba navzájom, prípadne na svojich blízkych, alebo vedúceho pracoviska, konzílium alebo manuál postupov pri riešení dilem v takto úzko špecifikovanej oblasti, ide o nesprávne a nezodpovedné riešenie vlastnej životnej situácie s vážnymi následkami s ohl'adom na telesno-duševne-duchovnú jednotu l'udskej prirodzenosti. Na druhej strane, pri rozhodovaní je nevyhnutná spolupráca a usmernenie informácií od všetkých zúčastnených, aby sa konkrétna osoba mohla slobodne rozhodnút' a osobnú zodpovednost' prevziat', ked'že zodpovednost' je výsostne dialogickou akost'ou l'udskej prirodzenosti. V súvislosti s antropologickým vymedzením ludskej prirodzenosti v kontexte dialogického personalizmu (Vrána; Vadíková, 2011, pp. 83 - 91, Rusnák), preto osobnú zodpovednost' a jej tiaž možno zdiel'at' v osobnom stretnutí v podobe dialógu, ale nie odovzdat', či prijat' a niest' za niekoho iného. Vtedy ide o porušenie nárokov na vlastnú identitu a je ohrozená integrita osoby, čím môže dôjst' k heteronómii osoby, na čo samotných zúčastnených upozorňuje aj svedomie v ich rozhodovacom procese (Vadíková, 2013, pp. 132 - 151).

Okrem osobnej zodpovednosti možno pri poskytovaní paliatívnej starostlivosti identifikovat' celý rad d’alších typov zodpovednosti (profesijnej, stavovskej, inštitucionálnej, globálnej, a pod.). Vzhl'adom k špecifikácii témy sme sa rozhodli sústredit' na problematiku osobnej zodpovednosti, ktorá je rozhodnutím autonómnej osoby pod vlastným menom odpovedat' na otázky z oblasti paliatívnej medicíny vo vzt'ahu k priamemu ataku bolest'ou. $V$ tomto zmysle budeme sledovat' aj dôsledky intímneho preživania vzt’ahu medzi náboženstvom a medicínou v rozhodovacom procese osoby.

Osobná zodpovednost' a paliatívna starostlivost': Osobnú zodpovednost' možno vzhl'adom $k$ terminológii dialogickej personalistickej etiky rozumiet' ako jedinečne autonómnu odpoved' dialogickej osoby guardiniovského typu (Guardini, 1950, p. 15, p. 23, p. 37) na volanie po mene $v$ otázkach, ktoré sa bytostne dotýkajú jej životného príbehu v centre interpersonálnych vzt'ahov. V tomto zmysle nie je možné ani poskytovatel'a, ani prijímatel'a starostlivosti viazat' povinnost'ou, ani príkazom, či sa odvolávat' na imperatív, ale vždy konkrétne pozývat' k spolupráci v boji s bolest'ou. Minimálnou požiadavkou zat'aženia, alebo otázkou, na ktorú sa očakáva odpoved', je humánnost' bolesti. Paliatívna medicína nedisponuje konkrétnym výpočtom l'udskej únosnosti bolesti, pretože tá je intímnou výpoved'ou jedinečnej skladby okolností v životnom príbehu človeka ako telesnej, duševnej a spirituálnej jednoty (Guardini, 2000). Preto možno rozhodnutie pre osobnú zodpovednost' axiologicky uchopit' a relačne vztiahnut' k zmyslu života a usporiadat' rebríček priorít (Wojtyla, 2003). Nenahraditel'nost', neodcudzitel'nost' a dôležitost' odpovede na bolest' vo vlastnom mene, tzn. rozhodnutie o bolesti, resp. prijatie bolesti vo vlastnom životnom príbehu ako aj v príbehu iných, preto patrí nielen k základným l'udským právam, ale vymedzuje l'udskú dôstojnost' v jej prirodzenosti, tzn. jej humánnost'.

Paliatívna medicína poskytuje starostlivost' človeku vo vel'mi náročnej životnej situácii. To môže niektoré zásadné podmienky priznania autonómie v rozhodovaní spochybňovat', či st'ažit' schopnost' rozlišovania, relativizovat' formuláciu potrieb, požiadaviek a rozhodnutí (Scheidová). V tomto ohl'ade je autotréning poskytovatel'a klúčovým prvkom zvládania zát'aže vyhrotených situácií, ked'že sa očakáva, že bude prijímatel'ovi starostlivosti oporou, povzbudením a spätnou väzbou v dialogickom zvládaní bolesti, a to akýmkol'vek spôsobom (formou ticha [Sarah], tichého gesta (Vadíková 2018), dialogickej blízkosti (Buber in Poláková, 1993), zdielania [Pompey], paliatívnej medicíny všetkých typov (fyzickej, duševnej, duchovnej). Poskytovatel' je prvotným štítom, obrannou líniou, útočiskom, prostredníkom, ale i sprostredkovatel'om, spolubojovníkom, zdielatel'om. V tomto zmysle je náročnost' spolubytia v bolesti preverením nielen zrelosti osobnosti po všetkých stránkach (telesnej, duševnej, profesijnej, duchovnej), ale najmä prirodzenej ludskosti v dynamike interpersonálnych vzt'ahov. Poskytovatel' je, odhliadnuc od všetkých iných profesijných znalostí a ludských akostí, pozvaný k osobnej odpovedi na výzvu k nádeji a sprostredkovaniu nádeje svojim zvereným [Pellegrino]. Vzhl'adom $\mathrm{k}$ tomu nádej dialogicky podmieňujeme angažovaním sa v centre vzt'ahov celým svojím bytím žitia svojho životného príbehu v zmysle marcelovského typu dôvery: 
Dúfam v teba kvôli nám (Marcel, pp. 123 - 124). Ide o špecificky dialogický rozmer personalistickej podstaty ludskej prirodzenosti, ktorá je živá angažovaním sa vo vzt'ahoch a identifikovaná menom, ktorým a v ktorom celým svojím bytím odpovedá v jadre svojej intimity - vo svedomí, na volanie dobra. Vernost' v odpovedi dobru je potvrdzovaná v každom jednotlivom rozhodnutí prostredníctvom svedomia (schopnosti rozpoznat' pravdu o dobre (Guardini, 1999), a zároveň inštancie pri obvinení z morálnej viny (Jaspers, p. 7)).

Koncepcia paliatívnej nádeje ako dialogicky žitého vzt'ahu medzi náboženstvom a medicínou: $V$ paliatívnej nádeji sa plne rozvíja, uskutočňuje a preveruje žitie vzt’ahu medzi náboženstvom a medicínou v konkrétnom životnom príbehu. Paliatívna nádej je liečivým prvkom akejkol'vek intenzity a akosti bolesti. Jej sila a účinnost' je podmienená schopnost'ou rozlišovania kauzality bolesti a nasmerovaním na dobro. Nie je priamo úmerná vynaloženému úsiliu, implicitne nezabezpečuje potlačenie bolesti, ale pôsobí na jej spracovanie na únosnú mieru zat'aženia $v$ jej telesnej, duševnej a duchovnej dimenzii. Paliatívna nádej je dialogická: v medziludských vzt’ahoch i vo vzt'ahu s Bohom, či inak povedané transcendentnom, prírodou, alebo inou formou transcendentnej autority podla vyznania náboženstva zúčastnených. Je možná aj pre tých, ktorý priamo odmietajú náboženskú vieru, ale pripúšt’ajú, že nie sú izolovaní a "čosi dobré" ich presahuje, to znamená že dôverujú a sú otvorení dialogickému pôsobeniu dobra vo svojom živote (tzv. "ludia dobrej vole"). Paliatívnej nádeji sa uzatvárajú tí, ktorých z rôznych príčin vzt’ahovo izoluje obava z ohrozenia vlastnej svojbytnosti a odmietajú privolit' k dialógu a zdiel'aniu. Tento stav však nie je nemenný a l'ahšie sa prekonáva, ak aspoň na jednej strane zúčastnených je dôvera v dobro a nádej v nadviazanie spoločenstva.

Vzt’ah náboženstva a medicíny je dôležitým faktorom v paliatívnej medicíne. Pod pojmom náboženstvo môžeme súborne rozumiet' taký komplexný obraz o fungovaní a usporiadaní sveta v myslení konkrétneho človeka, ktorý sa zakladá na istote poskytovanej l'udsky transcendentnou autoritou formou viery (Glasová, 2008, pp. 104 - 105). V rozhodovaní človeka potom tento obraz reprezentuje súbor dát, ktoré vstupujú do rozhodovacieho procesu ako informácie. $V$ ňom sa už tieto dáta neoverujú, ale podliehajú formovaciemu procesu konečnej formulácie prijímanej vo svedomí v mene autonómnej osoby, ked' tvorí, prijíma a uskutočňuje rozhodnutie. Svedomie v tomto procese funguje ako posledná inštancia overenia, či naozaj ide o pravdu o dobre a zároveň potvrdzujúcej inštancie, ktorá predkladá vo vedomí rozhodnutie osobe ako celku, aby ho prijala vo vlastnom mene, aby ju mohla následne chránit', ak by pochybovala o správnosti tohto rozhodnutia.

Na rozdiel od náboženstva je svetonázor takým komplexným obrazom o fungovaní a usporiadaní sveta v myslení konkrétneho človeka, ktorý sa zakladá na jeho osobnom presvedčení. Toto presvedčenie každý človek môže získat' odpoved'ou na základné životné otázky (odkial' prišiel; kam smeruje; ako vznikol svet; a pod.) (Glasová, 2008, pp. 108 - 109). Krest’anský svetonázor je darom cirkvi. Svedkom o pravde je samotný Ježiš Kristus a svätí. Náboženské presvedčenie vzniká rozhodnutím na základe svedectva evanjelia. V našom príspevku vychádzame guardiniovského krest'anského svetonázoru (Guardini, 1993).

V súlade s týmto krestanským svetonázorom je svedomie nástrojom na rozpoznanie odporúčaní o dobre rozhodovania ponúkaných samotnou autoritou - osobným Bohom. Deje sa to v dialógu - v modlitbe. Istota o pravdivosti dát a ich dobre je limit, nástroj, prevencia i ul'ahčenie v rozhodovaní. Avšak, je to samotná osoba ako celok, kto sa rozhoduje, a teda kto vo svojej odpovedi na ponuku (z)odpovedá vo vlastnom mene aj za následky a dôsledky tohto rozhodnutia. Ide teda 0 výnimočne ludskú schopnost', dar, o ktorý sa je nevyhnutné starat' a ho trénovat' (spytovanie svedomia), aby správne fungoval (Grundel). Napriek tomu, že môže byt' svedomie nezavinene mylné, je správne, a tak morálne záväzné, ako svedok o pravde (Skoblík, pp. 91 - 92).

Vo vzt’ahu k medicíne, ako prostriedku udržania, či znovuzískania zdravia a rade techník starostlivosti o zdravie, je náboženstvo korekciou limitov definície, spôsobu a starostlivosti o zdravie, 
ale i následkov a dôsledkov porušenia rozhodovania o zdraví a o starostlivosti o neho. Z hl'adiska krest'anského svetonázoru nie je správne pasívne prijímat' zdravotnícku starostlivost', ako by to bola iba akási údržba telesnej schránky, alebo duše, ale aktívne sa zúčastňovat' a spolupracovat' na rozhodovaní o nevyhnutných úkonoch, ktoré prispievajú k ozdravným procesom osoby v jednote jej telesnej, duševnej a tiež duchovnej dimenzie (aktívny informovaný súhlas).

V tomto zmysle je duchovná služba rovnako dôležitým prvkom starostlivosti (Slabý, 2004). Vzhl'adom k medicíne, napomáha k uisteniu o správnosti rozhodovania v otázkach zdravia, jeho limitov i miery zat’aženia ozdravnými procesmi s ohl'adom na celý životný príbeh osoby. Nenahraditel'nou sa stáva v terminálnych štádiách, alebo v stavoch akútnej nadmernej bolesti, kedy medicínske prostriedky nedokážu zmiernit' zát'až natol'ko, aby sa človek mohol nezávisle rozhodovat', či vôbec mysliet'. Uistenie potom spočíva v sprítomnení Božej lásky v technike zdiel'ania bolesti a obáv počas zomierania alebo neznesitel'ného utrpenia - spolubytie v zameraní na dobro a spoluúčast' na zdolávaní terminálnych okamihov života. Z hl'adiska krest'anského svetonázoru $v$ tejto forme duchovného sprevádzania nie je dôležitý fyzický, duševný, ale práve duchovný dotyk a prepojenie osôb v zdiel'aní utrpenia. Samotné zomieranie však nie je prenosné na inú osobu, ale je osobnou odpoved'ou na výzvu k rozlúčeniu sa a odpútaniu sa od pozemského sveta, medziludských vzt’ahov vrátane (Vadíková, 2012). Možno sa preto domnievat', že najintenzívnejší zážitok osobnej zodpovednosti človek prežíva v okamihu svojho odchodu z pozemského sveta.

V podmienkach paliatívnej starostlivosti je vzt’ah náboženstva a medicíny špecifikovaný zážitkom bolesti. Jedným z najčastejších omylov a následne nesprávneho prežívania vztahu medzi náboženstvom a medicínou v životnom príbehu osoby je ich vzájomná nevyváženost'. Prílišné spoliehanie sa na zázrak zo strany náboženského presvedčenia na úkor podrobeniu sa nevyhnutnej liečbe, alebo naopak, preceňovanie, až zbožstvenie medicíny a jej účinkov nielen na telesný a duševný, ale i duchovný stav. Vyplýva z pýchy človeka a nemiernemu preceňovaniu funkčnosti vzájomného vzt'ahu medzi náboženstvom a medicínou v osobnom živote človeka. Prehnaný autonomizmus zvádza k hl'adaniu kompenzácie (ceny) zdravia nejakým (hocakým) náboženským úkonom, a to bez pokorného dialógu v modlitbe a uistenia o adekvátnosti očakávaní prostredníctvom rozhovoru s poskytovatel'om duchovnej služby. Vo výzve k osobnej zodpovednosti človek na seba vzt'ahuje stvoritel'skú, ba až mesiášsku funkciu samospasitel'a. Na druhej strane neopodstatnený dohad o jednoznačne dokonanom výsledku zvoleného postupu medicínskych úkonov, bez rešpektu k osobitosti, nedokonalosti a špecifickej jedinečnosti ludského tela, či duše, môže vyústit' až do zbožstvenia poskytovatela starostlivosti, alebo vedca, či neosobného pokroku, vedy a podobne. Vyplýva zo zúfalej neistoty a nedôvery v Božiu prozretel'nost' a Božiu lásku a neschopnosti prijat' svoj údel ako súčast' svojho životného príbehu. Reprezentuje zlyhanie funkčnosti vzt'ahu medzi náboženstvom a medicínou v živote človeka. $V$ obidvoch prípadoch ide paradoxne o vzdanie sa osobnej zodpovednosti a vydanie sa napospas osudu, ktorým nie je Boh, ale fiktívna predstava o tom ako funguje a je usporiadaný svet - mýtus.

V podmienkach paliatívnej starostlivosti je vel'mi dôležité, aby žitie vzt’ahu medzi náboženstvom a medicínou bolo vyrovnanou odpoved'ou. Samotná bolest', ako komplexná osobná životná výzva, kladie túto požiadavku do híbky intimity človeka a súvisí s chápaním l'udskej dôstojnosti, rysov jeho identity a preveruje integritu jeho osobnosti. V náboženstve takto môže veriaci hl'adat' istotu o pravde ponúkaných možností medicíny, a v medicíne prostriedok k dialógu s Bohom a l'ud'mi. V akútnej bolesti takto nemusí čelit' výzvam sám, ale s Božou pomocou a v špecificky ludskom type zdiel'ania.

Viera v Boha a poznatky z oblasti medicíny umožňujú v podmienkach osobného stretnutia prijímatel'a a poskytovatel'a paliatívnej starostlivosti vznik tzv. paliatívnej nádeje, aj ked' nie sú nevyhnutnou zárukou jej funkčnosti. Je podmienená dôverou v Božiu lásku, milosrdenstvo a zmysel života, v l'udskost' zdiel'nosti okolitých l'udí, v účinky poskytnutej liečby, alebo aspoň v zmiernenie 
nadmernej bolesti tak, aby bola l'udsky únosná a dôverou v nepredlžovanie agónie $z$ akýchkol'vek dôvodov. Paliatívna nádej je zároveň istým terapeutickým nástrojom na zmiernenie následkov a dôsledkov pôsobenia nadmernej bolesti na telesnú, duševnú a duchovnú jednotu osoby. Je intímnou odpoved'ou na volanie po mene v podmienkach, kedy mysel' a vedomie už neumožňujú rozhodovací proces, ale svedomie kontinuálne retrospektívne potvrdzuje predchádzajúce rozhodnutie o dôvere v to najlepšie, čo má príst'. Ide o prepojenie náboženskej viery a dôvery v poznatky medicíny, ktoré by sa však stali nefunkčnými bez centrovania v interpersonálnych vzt'ahoch. Paliatívna nádej pôsobí výhradne prostredníctvom interpersonálneho zdiel'ania všetkých zúčastnených (prijímatel'a, poskytovatel'a starostlivosti a Boha), tzn. v zrelom žitom vyrovnanom vzt'ahu medzi náboženstvom a medicínou. Paradoxne, v osobnom stretnutí nie je natol'ko dôležité, aby si sprostredkovanie paliatívnej nádeje účastníci vzt’ahu uvedomovali a vedome ho rozvijali. Stačí detinská dôvera v dobro a jeho autoritu, tzn. že nastane to najlepšie, čo nastat' má. Na rozdiel od mýtického fanatického fatalizmu tu ide naviac o dôveru, že to bude naozaj to najlepšie, pretože o tom nerozhoduje prijímatel' sám, ani sa o tom nedohaduje, ba dokonca si ani nedokáže predstavit', čo Boh pripravil tým, ktorí ho milujú. [Pavol - List Korintanom]

Závery. Dialogická osoba je pozvaná žit' zodpovedne vyrovnaný vzt'ah medzi náboženstvom a medicínou. $\vee$ podmienkach poskytovania paliatívnej starostlivosti je vzt’ah medzi náboženstvom a medicínou špecifikovaný atakom bolesti, ktorého prekonanie je možné iba v osobnom stretnutí dialogickou formou zdiel'ania bolesti. Samotná bolest', ako komplexná osobná životná výzva, kladie túto požiadavku do híbky intimity človeka a súvisí s chápaním ludskej dôstojnosti, rysov jeho identity a preveruje integritu jeho osobnosti. Paliatívna nádej ako významný liečivý prvok v stavoch nadmernej bolesti je niečím natol'ko ludsky výnimočným, že $\mathrm{k}$ jej aplikácii a pôsobeniu nie je $v$ konečnom dôsledku potrebné ani zvláštne náboženské, ani špeciálne medicínske vzdelanie. Stačí úprimná nábožnost', dôvera v Božiu prozretel'nost', ochota zdiel'at' trápenie, dôvera v l'udskost' poskytovanej starostlivosti, vernost' odpovediam vo svedomí. Na druhej strane, k poskytovaniu paliatívnej nádeje je vo svedomí zaviazaný každý, kto stretne trpiacu l'udskú osobu bez ohl'adu na to, či ju o pomoc požiada, alebo nie. Forma, intenzita, kvalita nezávisí od neho samého, ale od všetkých zúčastnených. Paliatívna nádej je dialogický dar zniest’ nápor bolesti.

\section{References}

Buber, M. "A Sharing Silence" [Sdělující mlčení]. [Trans. Poláková, J.] In: Buber, M. "Talk", [Rozhovor], [Trans. Poláková, J. in Poláková, J.], (1993), Philosophy of Dialogue. Introduction into a One of a Stream of Philosphical Thinking in the 20. Century, [Filosofie dialogu. Uvedení do jednoho z proudů filosofického myšlení 20. století. Ukázky z děl.], FÚ AV ČR, Praha, pp. 63 - 64 [in Czech]

Pellegrino, E. (2011), "The Catholic Physician in an Era of Secular Bioethics", Linacre Quarterly, No. $78(1)$, pp. $13-28$

Glasová, K. (2008), Philosophy in Praxis of a Social Worker [Filozofia v praxi sociálneho pracovníka], VŠ Z a SP sv. Alžbety, Bratislava [in Slovak]

Grundel, J. (1990), "Obligatoriness and Outreach of the Conscience Appeal" ["Verbindlichkeit und Reichtweite des Gewissensanspruches"], Grundel, J. (editor), (1990), Conscience: subjektive Arbitrariness or the highest Norm [Das Gewissen: subjektive Willkur oder obererste Norm?], Patmos-Verlag, Dusseldorf, s. 99 - 126 [in German]

Guardini, R. (1950), About a Sense of an Alliance [Vom Sinn der Gemeinschaft], Arche, Zürich, 51 s. [in German]

Guardini, R. (1993), Ethics. Lectures ath the University of Munich [Ethik. Vorlesungen and der Univesität München] [Editors Mercker, H. - Marshall, M. - Franz, H.], Matthias-Grunewald- 
Verlag, München [in German]

Guardini, R. (1999), Good, Conscience and Concentration, [Dobro, svědomí a soustred'ováni]. [Trans. Lobkowicz, F.], Vyšehrad, Praha [in Czech]

Guardini, R. (2005), World and Person, [Svět a osoba], [Transl. Pohunková, D.], Trinitas, Svitavy [in Czech]

Scheidová, L. (2010), "Explanation of the Main Notions and of its Relations in the Palliative and Hospice Care" ["Vysvetlenie základných pojmov a ich vzt’ahov v rámci palatívnej a hospicovej liečby a starostlivosti"] [online] [cit. 2010.04.09], available at: http://hospice.cz/vysvetlenie. $\mathrm{html}$ [in Slovak]

Marcel, G. (1971), About a Philosophy of Hope [K filosofii naděje] [Transl. Dvořáková, V.], Vyšehrad, Praha [in Czech]

Pavol - apoštol "The Firts Letter to Corynth" ["Prvý List Korint'anom"] [online] [cit. 20.05.2019], available at: http://www.svatepismo.sk/listovat.php?kniha=53\&kapitola=2\&nv=off [in Slovak]

Pompey, H. (2004), Dying [Zomieranie], Dobrá kniha, Trnava, 183 s. [in Slovak]

Rusnák, P. (2018), "Another Man as a Gift in the Philosophy of Dialogue", ["Iný ako dar vo filozofii dialógu"], Rajský A, Wiesenganger M. Assistance to Another Man on a Virtue Way [Pomoc druhému na ceste cnosti], VEDA/Typi Universitatis Tyrnaviensis, Trnava, pp. 78 - 100 [in Slovak]

Sarah, R. (2017), The Power of Silence. Against the Dictatorship of Noise, [Sila ticha. Proti diktatúre hluku], [Trans. Košiar, J.], Lúč, Bratislava [in Slovak]

Skoblík, K. (1997), Preview of the Christian Ethics [Přehled krest'anské etiky], Karolinum, Praha [in Czech]

Slabý, A. (2004), "Spiritual Aspects of Palliative Medicine", ["Duchovné aspekty paliatívnej medicíny"], Vorliček J, Adam Z, Pospišilová Y, et al. Palliative Medicine [Paliativní medicína], Grada, Praha, pp. 449 - 455 [in Czech]

Vadíková, K. M. (2015), "The Gift of Hope in Care for Dying Persons", ["Dar nádeje v starostlivosti o zomierajúcich"], Paliat. med. lieč. boles. - Supl., 3, 2015; 8(S3), s. 27 - 31 [in Slovak]

Vadíková, K. M. (2011), Problems of conscience in the context of dialogical personalism [Problematika svedomia v kontexte dialogického personalizmu], FFTU, Trnava [in Slovak]

Vadíková, K. M. (2013), "Personal Axiology - Ethical Values in Praxis", ["Osobná axiológia - etické hodnoty v praxi"], Orbanová, E., Vadíková, K. M., Čechvala, O. (2013), Terminology of Philosophical Axiology [Terminológia filozofickej axiológie], FFTU, Trnava, s. 120 - 167 [in Slovak]

Vadíková, K. M. (2018), "The Value of the Dialogical Silence in the Palliative Care in a Hospice", ["Význam dialogického ticha v paliatívnej starostlivosti v hospici"], Molnárová Letovancová, K. (Ed.), Proceedings of 8th Annual of International Conference of Hospice and Palliative Care, F Z a SP Trnava, Trnava, s. 77 - 85 [in Slovak]

Vadíková, K. M. (2012), "Value of understanding for dying as for personal mystery in the circumstances of hospice and palliative care" ["Význam porozumeniu zomieraniu ako osobnému tajomstvu v podmiekach hospicovej a paliatívnej starostlivosti"], Paliat. Med. Lieč. Boles. - Supl. 2, 2012; 5 (S2). s. 46 - 48 [in Slovak]

Vrána, K. (1996), Dialogical personalism [Dialogický personalismus], Zvon, Praha, 63 s. [in Czech] Wojtyla, K. (2003), Love and Responsibility [Láska a zodpovednost] [Transl. Willets, H.], Metodickopedagogické centrum, Bratislava, $223 \mathrm{p}$. [in Slovak]

Wojtyla, K. (2000), Person and Act. Antropological Studies. Man and Morality [Osoba i czyn. Otaz inne studia antropologiczne. Czlowiek i moralnošč], Towarzystvo naukowe KUL, Lublin, 540 s. [in Polish]

\section{@ Katarina Maria Vadikova}

